\title{
Effects of Visual Loss in the Corpus Callosum in Rats Subjected to Sensory-Motor Training
}

\author{
Efectos de la Deprivación Visual en el Cuerpo Calloso \\ en Ratas Sometidas a Entrenamiento Sensoriomotriz
}

Iván Suazo Galdames; Bernarda López Farías \& Mario Cantín López

SUAZO, G. I.; LÓPEZ, F. B. \& CANTÍN, L. M. Effects of visual loss in the corpus callosum in rats subjected to sensory-motor training. Int. J. Morphol., 27(4):1031-1035, 2009.

SUMMARY: The purpose of this study was to analyze the changes in the dimensions of different portions of the corpus callosum in rats subjected to sensory-motor enriched environment with visual loss. We used 24 adult Sprague-Dawley rats divided into three groups: G1 $(n=7)$ control, G2 $(n=10)$ subjected to sensory-motor stimulation, and G3 $(n=7)$ subjected to sensory-motor stimulation followed by visual loss by retinal injury. The brains were extracted and the corpus callosum was divided into three parts of equal length, corresponding to the genu, mid-body, and splenium, and the callosal area was determined according to the method described by Aboitiz et al. (1992). We observed normal performance among animals in G2 and G3 in the enriched environment with a decrease in the area of the posterior third of the corpus callosum or splenium in G3. However, these differences were not statistically significant when compared with G1 and G2, which suggests that prior training to G3 retinal lesion favored the performance observed after the injury.

KEY WORDS: Corpus callosum; Esplenium; Visual cortex; Motor performance.

\section{INTRODUCTION}

The corpus callosum is the major telencephalic commissure, formed by the axons originating from different regions of the cerebral cortex and distributed according to a defined topographic organization (Aboitiz et al., 1989; Aboitiz, 1992; de Lacoste et al., 1985), and associating the composition of the regions of the corpus callosum at various specific functional sites (Innocenti et al., 1986; Seltzer \& Pandya, 1994, 2009).

Alterations in the shape and composition of the corpus callosum was reported by Olivares et al. (2002) in rats affected by prenatal malnutrition, which were consistent with the changes in the different regions of the cerebral cortex and corpus callosum, when developing rats were subjected to a series of nutritional deprivation (West \& Kemper, 1976; Tonkiss \& Galler, 1990), noxious stimulation (Zimmerberg \& Mickus, 1990; Gravel \& Hawkes, 1990), or exposure to an enriched environment (Fernandez et al. 1998; Inzunza et al., 2003).

The exposure of the animals to an enriched environment has been shown to cause morphological changes in various regions of the cortex and the fibers projected to it (Rosenzweig \& Bennett, 1972), and hence, training in these environments is considered to support the development of social, cognitive, and motor skills (David et al., 1993; Raine et al., 2003). The development of skills dependent on the kinesthetic information from the visual system (Imbiriba et al., 2006) has been described in connection with the motor function. Hence, it is presumed that the performance of the motor function in an enriched environment might be affected in subjects with visual loss.

With this background, the purpose of this study was to analyze the changes in the dimensions of different portions of the corpus callosum in rats subjected to sensory-motor enriched environment with visual loss.

\section{MATERIAL AND METHOD}

We used 24 adult Sprague-Dawley rats between 250 and $300 \mathrm{~g}$ of weight, obtained from ANEXPA Biotery, Talca, 
which were kept under conditions of social interaction in their home cage during the time between sessions, drinking water, and food ad libitum. The rats were divided randomly into three groups:

Group I $(n=7)=$ Used as a control and kept in cages without additional stimulation.

Group II $(\mathrm{n}=10)=$ Subjected to sensory-motor stimulation in the enriched environment for 10 days.

Group III $(n=7)=$ Subjected to sensory-motor stimulation in the enriched environment for 4 days, until they reached their habituation to the environment, after which the rats were blinded by injecting $95 \%$ alcohol in the vitreous chamber, in contact with the back wall. Before the injection, the rats were anesthetized with ethyl ether gas in an anesthesia induction chamber, and the corneal reflex was inhibited by the administration of $3 \%$ lidocaine in the bulbar conjunctiva. After the lesion was resumed, the stimulation program was carried out for the remaining 6 days.

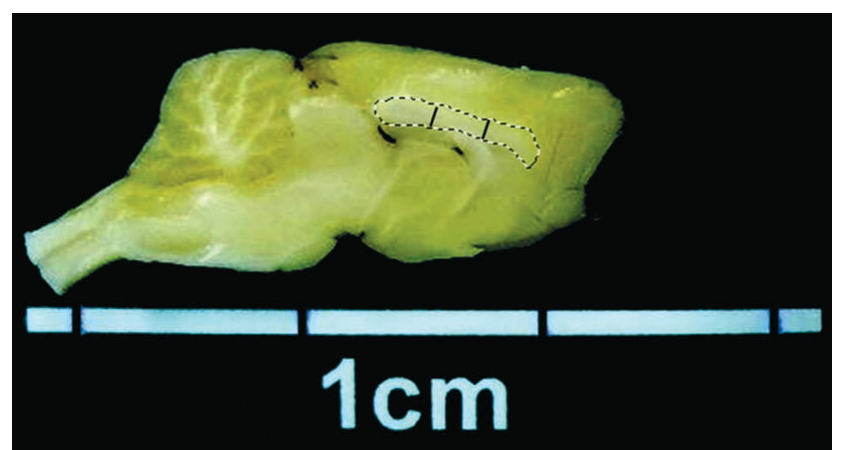

Fig. 1. Photographic of the midsaggital section of encephalum, The corpus callosum was divided into three parts.
The sensory-motor stimulation was performed in accordance with the paradigm of the enriched environment suggested by Rosenzweig et al. (1972), which included two daily sessions of stimulation, at 8:30-9:30 $\mathrm{h}$ and 18:30-19:30 $\mathrm{h}$ for 10 days.

After the period of stimulation, the rats were euthanized, and the brains obtained by dissection were maintained in $10 \%$ buffered formalin for 3 weeks (replaced every 5 days), and were subsequently sectioned sagittally (longitudinal fissure through the brain) and photographed in the medial side in both the hemispheres, using a digital camera (Panasonic LUMIX DMC-FX07®), standardized at a distance given by a photographic support medium.

The images were printed on Kodak® Photo paper, which measured the length of the corpus callosum from the anterior to the posterior pole (Fig. 1). Subsequently, the corpus callosum was divided into three parts of equal length: anterior part or genu, middle part or mid-body, and posterior part or the splenium. Each segment was cut and weighed, and its area was determined by comparison with the known weight of a paper equivalent area of $1 \mathrm{~cm}^{2}$, according to the method described by Aboitiz et al. (1992).

Based on the value of weight for each of the parts of the corpus callosum, descriptive statistics (mean, standard deviation, and variance) were obtained. The mean differences between the groups were compared (Groups I-II, Groups IIII, Groups II-III) by ANOVA test with a significance level of $p<0.05$. To establish the details of the statistical differences found between the groups, the statistical Scheffe test was employed.

Table I. Descriptive statistics of total weight of each one corpus callosum thirds. The mean area was calculated based on $1 \mathrm{~cm}^{2}=$ 0397 gr. *One corpus callosum in this group was lost due to problems in handling.

\begin{tabular}{llllllll}
\hline \multirow{3}{*}{ Group I } & & $\mathbf{n}$ & Min & Max & Mean & Mean area & SD \\
\cline { 3 - 7 } & Total & 14 & .019 & .038 & .02801 & 0.07055416 & .005088 \\
Anterior third & 14 & .0060 & .0117 & .009600 & 0.02418136 & .0015507 \\
\multirow{3}{*}{ Group II } & Middle third & 14 & .0058 & .0112 & .008286 & 0.02087154 & .0015124 \\
& Posterior third & 14 & .0059 & .0154 & .010143 & 0.02554912 & .0026821 \\
& Total & 20 & .023 & .040 & .02953 & 0.07438287 & .005096 \\
& Anterior third & 20 & .0077 & .0147 & .010115 & 0.02547859 & .0017005 \\
\multirow{3}{*}{ Group III ${ }^{*}$} & Middle third & 20 & .0064 & .0139 & .008745 & 0.02202771 & .0018083 \\
& Posterior third & 20 & .0076 & .0152 & .010610 & 0.02672544 & .0021720 \\
& Total & 13 & .024 & .031 & .02692 & 0.06780856 & .002453 \\
& Anterior third & 13 & .0078 & .0127 & .010415 & 0.02623426 & .0014023 \\
& Middle third & 13 & .0050 & .0090 & .007600 & 0.01914358 & .0010083 \\
& Posterior third & 13 & .0067 & .0115 & .008785 & 0.02212846 & .0014433 \\
\hline
\end{tabular}


Table II. ANOVA analysis of variance in weight of the corpus callosum analyzed segments.

\begin{tabular}{llccccc}
\hline \multirow{3}{*}{ Total weight } & Square summation & $\mathbf{d f}$ & Mean square & $\mathbf{F}$ & Sig. \\
\cline { 2 - 6 } Anterior third & Inter-groups & .000 & 2 & .000 & 1.364 & .266 \\
& Intra-group & .001 & 44 & .000 & & \\
& Total & .001 & 46 & & & \\
& Inter-groups & .000 & 2 & .000 & .932 & .401 \\
& Intra-group & .000 & 44 & .000 & & \\
\cline { 2 - 6 } Middle third & Total & .000 & 46 & & & \\
& Inter-groups & .000 & 2 & .000 & 2.184 & .125 \\
& Intra-group & .000 & 44 & .000 & & \\
& Total & .000 & 46 & & & \\
Posterior third & Inter-groups & .000 & 2 & .000 & 2.841 & .069 \\
& Intra-group & .000 & 44 & .000 & & \\
& Total & .000 & 46 & & & \\
\hline
\end{tabular}

\section{RESULTS}

Table III. Results of Shaffer's test applying.

\begin{tabular}{|c|c|c|c|}
\hline Scheffé Test & Groups & Groups & Sig. \\
\hline \multirow[t]{6}{*}{ Total weight } & I & II & .635 \\
\hline & & III & .821 \\
\hline & II & I & .635 \\
\hline & & III & .281 \\
\hline & III & I & .821 \\
\hline & & II & .281 \\
\hline \multirow[t]{6}{*}{ Anterior third } & I & II & .648 \\
\hline & & III & .415 \\
\hline & II & I & .648 \\
\hline & & III & .868 \\
\hline & III & I & .415 \\
\hline & & II & .868 \\
\hline \multirow[t]{6}{*}{ Middle third } & I & II & .695 \\
\hline & & III & .517 \\
\hline & II & I & .695 \\
\hline & & III & .125 \\
\hline & III & I & .517 \\
\hline & & II & .125 \\
\hline \multirow[t]{6}{*}{ Posterior third } & I & II & .828 \\
\hline & & III & .279 \\
\hline & II & I & .828 \\
\hline & & III & .073 \\
\hline & III & I & .279 \\
\hline & & II & .073 \\
\hline
\end{tabular}

The groups of rats subjected to sensory-motor stimulation showed normal behavior with respect to the terms described by Rosenzweig et al.

The highest values of the corpus callosum area were found in the group of rats subjected to stimulation without retinal injury (Group II), and in groups I and II, the region of the corpus callosum, i.e., splenium, had the greatest area, while in group III, further development was found in the genu region. These results are shown in Table I.

However, the intra-and intergroup variations in the three parts of the corpus callosum were not significant (Tables II and III).

\section{DISCUSSION}

In our study, we found a decrease in the area of the posterior part of the corpus callosum or splenium, in the group subjected to sensory-motor stimulation with retinal visual loss owing to injury, although these differences were not statistically significant when compared with the control group subjected only to sensory-motor stimulation. These results suggest a decrease in the thalamocortical projections that are directed to the visual cortex, which did not significantly affect the performance of the animals in this group in the stimulation chamber. Hence, in the absence of visual information that involves the postural mechanisms taking part in the normal activity in the enriched environment, the articular, spinal, and vestibular 
proprioceptive elements appear to be sufficient for the proper sensory-motor performance in the stimulation chamber. The differences found, although not significant, between the groups subjected to stimulation with and without retinal lesion in the region of the corpus callosum, i.e., splenium, suggest that the sensory-motor stimulation can cause changes in the visual cortex, which has already been reported in the literature (Pascual \& Figueroa, 1996).
In our study, rats subjected to visual deprivation had a period of 4 days of habituation to the environment. This training period seems to have affected the normal performance later, after experimental retinal damage, which reinforces the idea that the sensory-motor stimulation favors early plastic changes in the cerebral cortex and facilitates rehabilitation in the case of injury.

SUAZO, G. I.; LÓPEZ, F. B. \& CANTÍN, L. M. Efectos de la deprivación visual en el cuerpo calloso en ratas sometidas a entrenamiento sensoriomotriz. Int. J. Morphol., 27(4):1031-1035, 2009.

RESUMEN: El propósito de este estudio fue analizar los cambios en las dimensiones de las diferentes porciones del cuerpo calloso en ratas sometidas a un medio ambiente enriquecido sensoriomotriz con deprivación visual. Se utilizaron 24 ratas Sprague Dawley adultas divididas en tres grupos: $\mathrm{G} 1(\mathrm{n}=7)$ control; $\mathrm{G} 2(\mathrm{n}=10)$ sometidas a estimulación sensoriomotriz y $\mathrm{G} 3(\mathrm{n}=7)$ sometidas a estimulación sensoriomotriz seguida de deprivación visual por lesión retiniana. Se obtuvieron los encéfalos y el cuerpo calloso fue dividido en tres tercios correspondiendo a la rodilla, tercio medio y esplenio. El área callosal se determinó de acuerdo al método descrito por Aboitiz et al. (1992). Encontramos un rendimiento normal de los animales de G2 y G3 en el medio ambiente enriquecido, con disminución en el área del tercio posterior o esplenio del cuerpo calloso en G3, aunque estas diferencias no fueron estadísticamente significativas al compararlas con el G1 y G2, lo que sugiere que el entrenamiento previo a la lesión retiniana de G3 favoreció el desempeño obtenido posterior a la lesión.

PALABRAS CLAVE: Cuerpo calloso; Esplenio; Cortex visual; Rendimiento motor.

\section{REFERENCES}

Aboitiz, F. Brain connections: interhemispheric fiber systems and anatomical brain asymmetries in humans. Biol. Res., 25:51-61, 1992.

Aboitiz, F.; Scheibel, A. B.; Fisher, R. S. \& Zaidel, E. Fiber composition of the human corpus callosum. Brain Res, 598:143-53, 1992.

Aboitiz, F.; Zaidel, E. \& Scheibel, A. B. Variability in fiber composition in different regions of the corpus callosum in humans. Anat. Rec., 223:6A, 1989.

David, A. S.; Wacharasindhu, A. \& Lishman, W. A. Severe psychiatric disturbance and abnormalities of the corpus callosum: Review and case series. J. Neurol. Neurosurg. Psychiatry, 56:85-93, 1993.

de Lacoste, M. C.; Kirkpatrick, J. B. \& Ross, E. D. Topography of the human corpus callosum. J. Neuropathol. Exp. Neurol., 44:578-91, 1985.

Fernández, V.; Bravo, H.; Sanhueza, M. \& Inzunza, O. NADPH-d positive neurons in the developing somatosensory cortex of the rat: effects of early and late environmental enrichment. Brain Res. Dev. Brain Res., 107(2):299-307, 1998.
Gravel, C. \& Hawkes, R. Maturation of the corpus callosum of the rat: I. Influence of thyroid hormones on the topography of callosal projections. J. Comp. Neurol., 291(1):128-46, 1990.

Imbiriba, L. A.; Rodrigues, E. C.; Magalhães, J. \& Vargas, C. D. Motor imagery in blind subjects: The influence of the previous visual experience. Neurosci. Lett., 400:1815, 2006.

Innocenti, G. M.; Clarke, S. \& Kraftsik, R. Interchange of callosal and association projections in the developing visual cortex. J. Neurosci., 6:1384-409, 1986.

Inzunza, O.; Bravo, H. \& Fernández, V. Environmental enrichment during early postnatal development, decreases parvalbumin expression in the rat somatosensory cortex. Int. J. Morphol., 21(3):181-9, 2003.

Olivares, R.; Soto-Moyano, R.; Hernández, A. \& Aboitiz, F. La malnutrición prenatal proteica afecta el desarrollo del cuerpo calloso anterior. Rev. Chil. Anat., 20(2):159-63, 2002.

Pascual, R. \& Figueroa, H. Effects of preweaning 
sensorimotor stimulation on behavioral and neuronal development in motor and visual cortex of the rat. Biol. Neonate, 69:399-404, 1996.

Raine, A.; Lencz, T.; Taylor, K.; Hellige, J. B.; Bihrle, S.; Lacasse, L.; Lee, M.; Ishikawa, S. \& Colletti, P. Corpus callosum abnormalities in psychopathic antisocial individuals. Arch. Gen. Psychiatry, 60:1134-42, 2003.

Rosenzweig, M. R. \& Bennett, E. L. Cerebral changes in rats exposed individually to an enriched environment. $J$. Comp. Physiol. Psychol., 80:304-13, 1972.

Rosenzweig, M. R.; Bennett, E. L. \& Diamond, M. C. Brain changes in response to experience. Scient. Am., 226:229,1972 .

Seltzer, B. \& Pandya, D. N. Parietal, temporal, and occipital projections to cortex of the superior temporal sulcus in the rhesus monkey: A retrograde tracer study. J. Comp. Neurol., 343:445-63, 1994.

Seltzer, B. \& Pandya, D. N. Posterior cingulate and retrosplenial cortex connections of the caudal superior temporal region in the rhesus monkey. Exp. Brain Res., 195:325-34, 2009.

Tonkiss, J. \& Galler, J. R. Prenatal protein malnutrition and working memory performance in adult rats. Behav. Brain Res., 40(2):95-107, 1990.

West, C. D. \& Kemper, T. L. The effect of a low protein diet on the anatomical development of the rat brain. Brain Res., 107(2):221-37, 1976.

Zimmerberg, B. \& Mickus, L. A. Sex differences in corpus callosum: Influence of prenatal alcohol exposure and maternal undernutrition. Brain Res., 537(1-2):115-22, 1990.
Correspondence to:

Prof. Dr. Iván Suazo Galdames

Department of Morphology

Avenida Lircay s/n Oficina №104

Universidad de Talca, CHILE

Phone: 56-71-201576

Email: isuazo@utalca.cl

Received: 12-06-2009

Accepted: 28-09-2009 
